University of Nebraska - Lincoln

DigitalCommons@University of Nebraska - Lincoln

Agronomy \& Horticulture -- Faculty Publications

Agronomy and Horticulture Department

2005

Nitrogen supply affects root:shoot ratio in corn and velvetleaf

(Abutilon theophrasti)

\author{
Kimberly D. Bonifas \\ University of Nebraska-Lincoln \\ Daniel T. Walters \\ University of Nebraska-Lincoln \\ Kenneth G. Cassman \\ University of Nebraska-Lincoln, kcassman1@unl.edu \\ John L. Lindquist \\ University of Nebraska-Lincoln, jlindquist1@unl.edu
}

Follow this and additional works at: https://digitalcommons.unl.edu/agronomyfacpub

Part of the Plant Sciences Commons

Bonifas, Kimberly D.; Walters, Daniel T.; Cassman, Kenneth G.; and Lindquist, John L., "Nitrogen supply affects root:shoot ratio in corn and velvetleaf (Abutilon theophrasti)" (2005). Agronomy \& Horticulture -Faculty Publications. 416.

https://digitalcommons.unl.edu/agronomyfacpub/416

This Article is brought to you for free and open access by the Agronomy and Horticulture Department at DigitalCommons@University of Nebraska - Lincoln. It has been accepted for inclusion in Agronomy \& Horticulture -Faculty Publications by an authorized administrator of DigitalCommons@University of Nebraska - Lincoln. 


\section{Nitrogen supply affects root:shoot ratio in corn and velvetleaf (Abutilon theophrasti)}

\author{
Kimberly D. Bonifas \\ Daniel T. Walters \\ Kenneth G. Cassman \\ Department of Agronomy and Horticulture, \\ University of Nebraska, Lincoln, NE 68583-0915 \\ John L. Lindquist \\ Corresponding author. Department of Agronomy \\ and Horticulture, University of Nebraska, Lincoln, \\ NE 68583-0915; jlindquist1@unl.edu
}

\begin{abstract}
Competitive outcome between crops and weeds is affected by partitioning of new biomass to above- and belowground plant organs in response to nutrient supply. This study determined the fraction of biomass partitioned to roots vs. shoots in corn and velvetleaf in response to nitrogen $(\mathrm{N})$ supply. Pots measuring $28 \mathrm{~cm}$ in diam and $60 \mathrm{~cm}$ deep were embedded in the ground and each contained one plant of either corn or velvetleaf. Each plant received one of three $N$ treatments: 0,1 , or 3 $\mathrm{g} \mathrm{N}$ applied as ammonium nitrate in 2001, and 0, 2, or $6 \mathrm{~g} \mathrm{~N}$ in 2002. Measurements of total above- and belowground biomass were made at 10 sampling dates during each growing season. The root:shoot ratio decreased over time for both corn and velvetleaf as a result of normal plant growth and as $\mathrm{N}$ supply increased. Root: shoot ratio was greater for corn than for velvetleaf at comparable stages of development and at all levels of $\mathrm{N}$ supply. Both corn and velvetleaf display true plasticity in biomass partitioning patterns in response to $\mathrm{N}$ supply. Velvetleaf root:shoot ratio increased by 46 to $82 \%$ when $\mathrm{N}$ was limiting in 2001 and 2002, respectively, whereas corn root:shoot ratio increased by only 29 to $45 \%$. The greater increase in biomass partitioned to roots by velvetleaf might negatively impact its ability to compete with corn for light when $\mathrm{N}$ supply is limited.
\end{abstract}

Nomenclature: Velvetleaf, Abutilon theophrasti Medic., ABUTH; corn, Zea mays L.

Key words: Biomass partitioning, ontogenetic drift, optimal partitioning theory, phenology.
Corn production is vital to agriculture in the United States, with an estimated annual farm gate value of $\$ 23$ billion (USDA 2005). Velvetleaf causes considerable economic loss in corn and soybean [Glycine $\max$ (L.) Merr.] in the United States (Spencer 1984) and has the potential to cause up to $80 \%$ yield loss in corn when not adequately controlled (Lindquist et al. 1996). While market prices have continued to decline in recent years, input costs for nitrogen fertilizer and weed control measures continue to rise, leading to a decreased profit margin (Liebman et al. 2001). Along with increasing control costs, factors such as herbicide resistance and heightened environmental awareness have led to ecologically based weed management programs that focus on how components such as climate, edaphic properties, and resource availability affect crop and weed competitiveness (Murphy and Lindquist 2002).

The quantity of roots plants produce and the ability of those roots to take up $\mathrm{N}$ will affect competition, and plants competing for $\mathrm{N}$ are capable of showing plasticity in root growth and $\mathrm{N}$ uptake (Gedroc et al. 1996; Harmens et al. 2000; McConnaughay and Coleman 1999; Reynolds and D'Antonio 1996). An understanding of the effects of $\mathrm{N}$ supply on crop and weed growth and competition is critical because $\mathrm{N}$ inputs are required to sustain corn yields at current levels.

Corn utilizes the $\mathrm{C}_{4}$ photosynthetic pathway, whereas velvetleaf utilizes the $\mathrm{C}_{3}$ photosynthetic pathway. One of the functional differences that occurs as a result of the different photosynthetic pathways is photosynthetic $\mathrm{N}$ use efficiency (PNUE), the ratio of photosynthetic rate to $\mathrm{N}$ content in the leaf. PNUE is greater in $\mathrm{C}_{4}$ than in $\mathrm{C}_{3}$ plants (Brown 1978, 1985; Sage and Pearcy 1987). Therefore, it could be hypothesized that when $\mathrm{N}$ supply is limited, $\mathrm{C}_{3}$ plants will have to increase their root growth proportionally more than $\mathrm{C}_{4}$ plants to maintain a sufficient level of tissue $\mathrm{N}$ to sustain photosynthetic rates and dry matter accumulation.

The principal cause of yield loss in corn due to velvetleaf is competition for light (Lindquist and Mortensen 1999). Velvetleaf often grows taller than corn by mid-season, thus shading corn leaves (Roeth 1987). Competition for light, however, is also affected by competition for belowground resources. Velvetleaf might no longer be such a strong competitor for light if it is forced to invest more biomass in root production and less in stem and leaf production when soil $\mathrm{N}$ supply is limiting.

Optimal partitioning theory predicts that, in response to a resource gradient, plants will optimize overall growth rate by making all resources equally limiting and adjust their biomass partitioning patterns to obtain the most limiting resource (Hilbert 1990; Mooney et al. 1985; Robinson 1986). Plants that encounter limited nutrient or water supply are expected to partition more biomass to their roots and less to their stems and leaves. Accordingly, in limiting light environments, plants are expected to partition more new biomass to stem and leaf production and less to root production. Several documented cases exist where plants respond in accordance with optimal partitioning theory (Mooney et al. 1985; Reynolds and D'Antonio 1996). However, it has been argued that some of these cases might result instead from changes in partitioning during normal plant growth and development (Coleman et al. 1994; Gedroc et al. 1996; McConnaughay and Coleman 1999). Ontogenetic drift is a term used to describe the phenotypic changes that occur as a result of normal plant growth and 
development (Evans 1972). Because plants growing under different environmental conditions have different growth rates, plants of the same age might not be the same size or at the same developmental stage and are not necessarily ontogenetically identical (Evans 1972).

Ontogenetic drift can create potential problems in the interpretation of data from experiments on biomass partitioning. If optimal partitioning theory holds true, then plants grown in limiting soil nutrient environments will partition a larger percentage of new biomass to roots as opposed to shoots, and they will have a higher root:shoot ratio. However, early in ontogeny plants will have a higher root:shoot ratio because of normal processes of early root growth and establishment (Bazzaz et al. 1989). A key issue, therefore, is whether a higher root:shoot ratio observed in plants grown in low nutrient environments results from plasticity predicted by optimal partitioning theory or by slowed growth rates and stress-induced differences in stage of development.

The terms "apparent plasticity" and "true plasticity" have been used to describe differences observed in biomass partitioning patterns, where apparent plasticity is attributed to ontogenetic drift coupled with plasticity in growth rates, whereas true plasticity results from actual plasticity in biomass partitioning patterns (McConnaughay and Coleman 1999). If there is no true plasticity, plants growing at different rates will have different root:shoot ratios when compared at the same time, but their root:shoot ratios will be the same when compared at similar sizes or developmental stages.

According to optimal partitioning theory, both corn and velvetleaf will display true plasticity and partition a larger percentage of their biomass to roots and a smaller percentage of their biomass to shoots when $\mathrm{N}$ supply is limited. This shift in biomass partitioning in response to limiting $\mathrm{N}$ will result in an increase in root:shoot ratio along with a concomitant decrease in leaf area ratio (LAR, $\mathrm{m}^{2}$ leaf $\mathrm{g}^{-1}$ total biomass). Owing to PNUE differences in the $\mathrm{C}_{3}$ versus $\mathrm{C}_{4}$ metabolic pathways, we expect velvetleaf to increase its root growth more than corn when $\mathrm{N}$ is limiting to remain competitive and maintain its $\mathrm{C}_{3}$ photosynthetic rates. As a result, we expect velvetleaf to have a larger tradeoff than corn between root growth and shoot growth when $\mathrm{N}$ is limiting. The objective of this research was to quantify and compare biomass partitioning patterns of corn and velvetleaf in response to a range of $\mathrm{N}$ supply levels - from deficient to adequate. Any effects that $\mathrm{N}$ supply has on biomass partitioning patterns will directly affect aboveground acquisition of light and, subsequently, the outcome of competition between the two species.

\section{Materials and Methods}

\section{Experimental and Treatment Design}

A field experiment was conducted in 2001 and 2002 at the University of Nebraska-Lincoln. Experimental plants were grown in large pots $(28 \mathrm{~cm}$ diam by $60 \mathrm{~cm}$ deep) filled with a 50:50 sand:soil mixture and embedded in the ground to emulate the environmental conditions experienced by field-grown plants, especially with regard to temperature. Each pot had seven $1.8 \mathrm{~cm}$ diam holes in their bottom to allow for drainage. Pots were buried flush with the soil surface on $1 \mathrm{~m}$ centers. Rows of corn were planted between the rows of pots and around the edge of the site to more closely simulate field conditions and provide an added wind buffer for the treated plants in 2002. Total density, including potted plants, was 1 plant $\mathrm{m}^{-2}$ in 2001 and 5 plants $\mathrm{m}^{-2}$ in 2002.

The experiment was arranged in three replicate blocks across the field slope in a randomized complete block design. Blocks contained 10 replicate sample pots per treatment to accommodate for weekly destructive sampling. Each pot contained one corn or velvetleaf plant and received one of three $\mathrm{N}$ treatments. The $\mathrm{N}$ treatments administered were 0,1 , or $3 \mathrm{~g} \mathrm{~N}$ per pot in 2001, and 0,2 , or $6 \mathrm{~g} \mathrm{~N}$ per pot in 2002. The $\mathrm{N}$ treatments were increased in 2002 because corn plants reached a maximum biomass of over $300 \mathrm{~g}$ plant $^{-1}$ in 2001 . Assuming a whole plant $\mathrm{N}$ concentration of $2 \%$, a $300 \mathrm{~g}$ plant requires $6 \mathrm{~g} \mathrm{~N}$. Therefore, the increase was made to ensure adequate $\mathrm{N}$ supply for corn to reach its potential biomass in 2002 . The $\mathrm{N}$ treatments were applied at planting in the form of ammonium nitrate dissolved in $500 \mathrm{ml}$ distilled water. Macro and micronutrients other than $\mathrm{N}$ were non-limiting and provided by means of a weekly addition of $250 \mathrm{ml}$ of a dilute nutrient solution containing $0.15 \mathrm{~g} \mathrm{KCl}, 0.31 \mathrm{~g} \mathrm{CaCl}_{2} \cdot 2 \mathrm{H}_{2} \mathrm{O}, 0.09 \mathrm{~g}$ $\mathrm{MgSO}_{4} \cdot 7 \mathrm{H}_{2} \mathrm{O}, 0.04 \mathrm{KH}_{2} \mathrm{PO}_{4}, 5.1 \times 10^{-4} \mathrm{~g} \mathrm{H}_{3} \mathrm{BO}_{3}, 5.9$ $\times 10^{-4} \mathrm{~g} \mathrm{MnCl}_{2} \cdot 4 \mathrm{H}_{2} 0,2.2 \times 10^{-4} \mathrm{~g} \mathrm{ZnSO}_{4} \cdot 7 \mathrm{H}_{2} 0,5.0 \times$ $10^{-5} \mathrm{~g} \mathrm{CuSO}_{4} \cdot 5 \mathrm{H}_{2} \mathrm{O}, 6.5 \times 10^{-5} \mathrm{~g} \mathrm{Na}_{2} \mathrm{MoO}_{4} \cdot 2 \mathrm{H}_{2} \mathrm{O}$, and $2.2 \times 10^{-3} \mathrm{~g} \mathrm{FeCl}_{3} \cdot 6 \mathrm{H}_{2} 0$. Soil water supply was measured weekly and added as needed with a drip irrigation system to maintain adequate soil moisture throughout the experiment.

\section{Data Collection}

Plants were destructively sampled weekly in all treatments for 10 wk during the growing season. Corn reached R1 to R2 (anthesis to blister) and velvetleaf began to flower at 10 wk. Sampling began 1 wk after emergence in 2001 and 2 wk after emergence in 2002. Plant height and growth stage were recorded and plants were cut at the soil surface at each sampling date. Green leaf area was measured using a leaf area meter ${ }^{1}$ and aboveground plant parts were separated into stems, leaves, dead leaves, and reproductive tissues. Sampled pots were pulled from the ground and roots carefully separated from the soil mixture using a gentle stream of water. After 10 wk of plant growth there was no obvious constriction of root growth and roots rarely grew outside the pot bottom. Above- and belowground tissues were dried at 60 C to constant weight.

Soil samples were taken from pots at each sampling date prior to extraction of the root systems to determine if soil water content was being maintained at adequate levels in all treatments. Approximately $200 \mathrm{~g}$ of loose soil was taken for gravimetric water content analysis. Soil temperature was monitored both inside and outside pots to determine any temperature differences at five and three randomly selected locations in 2001 and 2002, respectively. Pairs (one inside and one outside the pot) of temperature loggers ${ }^{2}$ were placed $5 \mathrm{~cm}$ below the soil surface to $\log$ hourly temperatures throughout the experiment.

\section{Statistical Analysis}

Statistical analyses were conducted using SAS System for Windows, ${ }^{3}$ version 8 . Values of root:shoot ratio and total 


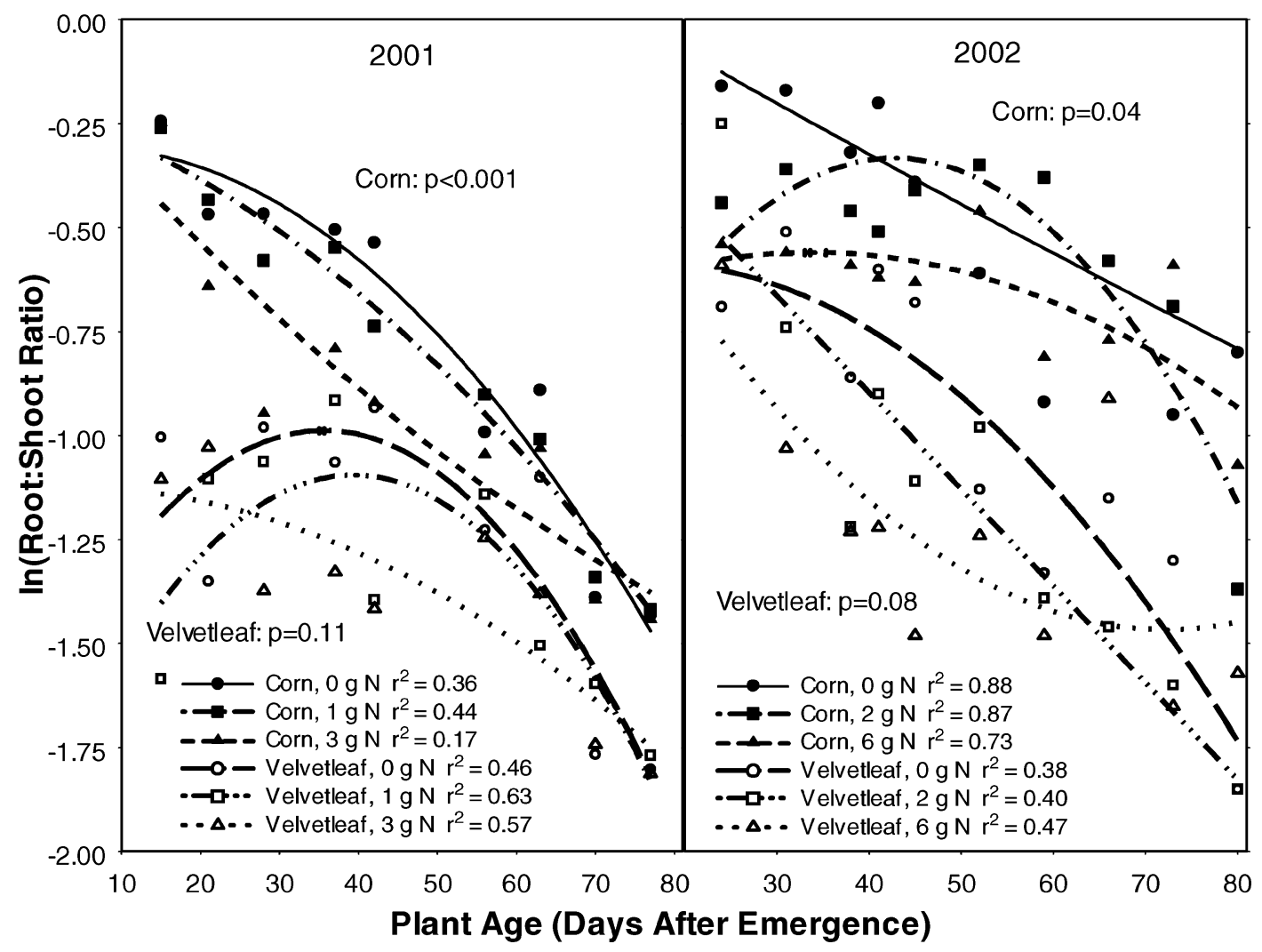

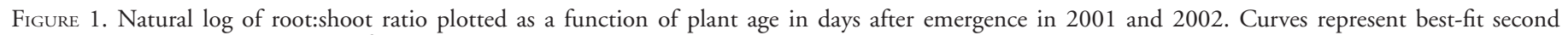

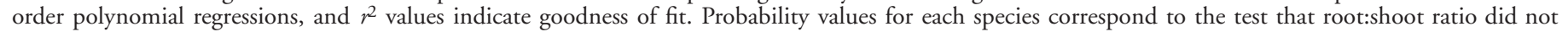
differ across nitrogen treatments.

biomass were natural $\log$ transformed prior to analysis to remove variance heterogeneity. Biomass partitioning patterns were determined by comparing root:shoot ratio over time and plant size using a quadratic model in the Proc Mixed procedure (Littell et al. 1996). The model compared the relationship between root:shoot ratio and plant age or plant size across species and $\mathrm{N}$ treatments. Because of the quadratic effects observed in the Proc Mixed results, second order polynomial curves were fitted for each species and $\mathrm{N}$ level. Leaf area ratio (total leaf area/total plant dry weight) also was compared and plotted as a function of plant size and fitted with second order polynomial curves for each species and $\mathrm{N}$ level.

\section{Results and Discussion}

Measurements of gravimetric soil water content indicated adequate water availability throughout the experiment (data not shown). Average soil temperature inside and outside (23.1 C) pots did not differ in 2001, but soil temperature outside the pots was slightly greater $(24.0 \mathrm{C})$ than inside pots $(23.5 \mathrm{C})$ in 2002 . This temperature discrepancy was attributed to drought during the 2002 growing season. Slightly cooler soil temperatures inside the pots resulted from the adequate and consistent water supply.

Corn and velvetleaf root:shoot ratio varied with plant age at all levels of $\mathrm{N}$ supply in 2001 and 2002, indicating both species displayed ontogenetic drift in biomass partitioning (Figure 1). Age comparisons of root:shoot ratio also showed that both corn and velvetleaf increased biomass partitioning to roots when $\mathrm{N}$ was limiting. However, the response over time cannot be attributed to true plasticity in biomass partitioning patterns because rate of development might vary in response to $\mathrm{N}$ supply treatments.

Corn and velvetleaf root:shoot ratio also varied as a function of plant size, indicating true plasticity in biomass partitioning (Figure 2). Size comparisons reveal root:shoot ratio decreased as plant size increased and that both species tended to partition more biomass to roots versus shoots when $\mathrm{N}$ was limiting. Therefore, both species appear to increase their root growth in order to increase $\mathrm{N}$ uptake and maintain photosynthesis and growth when $\mathrm{N}$ is limiting. Moreover, both species modified partitioning in accordance with optimal partitioning theory.

The root:shoot ratio response to $\mathrm{N}$ supply (Figure 2) also indicates that at lower $\mathrm{N}$ levels, both species partitioned more biomass to roots during early and intermediate stages of growth. At later stages of growth, both species began to partition less biomass to roots at limiting $\mathrm{N}$ than plants at the high level of $\mathrm{N}$ supply. These findings are similar to those reported by McConnaughay and Coleman (1999) for the weed species velvetleaf, common lambsquarters (Chenopodium album L.), and Pennsylvania smartweed (Polygonum pensylvanicum L.). The decline in biomass partitioning to roots they observed for nutrient stressed plants occurred at earlier growth stages than in this study.

To illustrate the magnitude of changes in root:shoot ratio in response to $\mathrm{N}$ supply, untransformed values were compared among $\mathrm{N}$ supply treatments for various corn and velvetleaf size classes. Size classes were selected based on a visual assessment of the total biomass data. Same size comparisons 


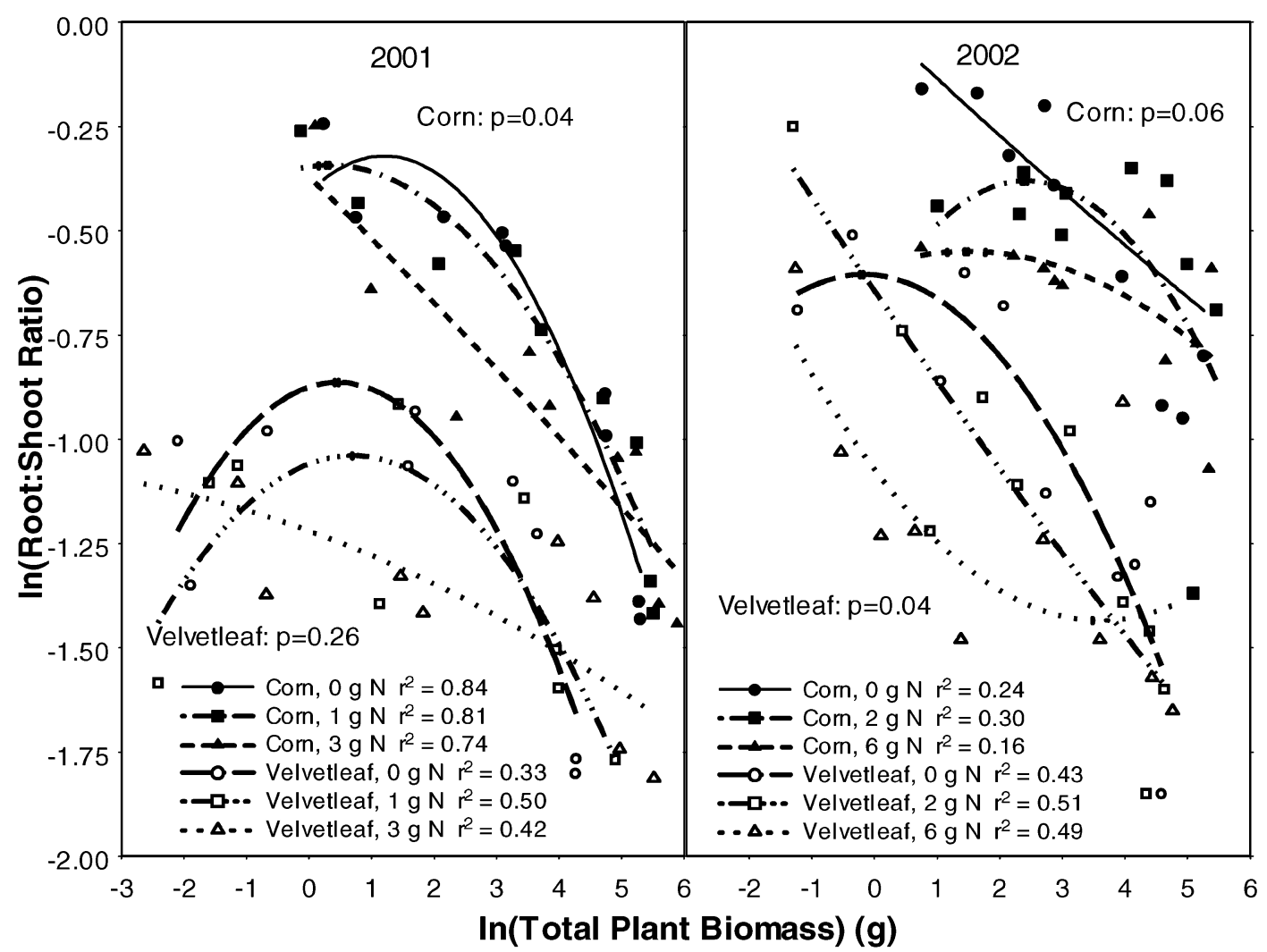

Figure 2. Natural log of root:shoot ratio plotted as a function of natural log of total plant biomass $\left(\mathrm{g} \mathrm{plant}^{-1}\right)$ in 2001 and 2002. Curves represent bestfit second order polynomial regressions, and $r^{2}$ values indicate goodness of fit. Probability values for each species correspond to the test that root:shoot ratio did not differ across nitrogen treatments.

indicate that corn and velvetleaf root:shoot ratio differ among $\mathrm{N}$ supply treatments at both small and intermediate sizes but not when plants were large (Table 1). These results aid in visualizing the critical growth periods when $\mathrm{N}$ influences root growth and development of the plant.

Velvetleaf had a lower root:shoot ratio than corn at all stages of growth and development and at all levels of $\mathrm{N}$ supply (Table 1; Figure 2). Velvetleaf allocates more biomass to shoots and less to roots at all sizes and levels of N, potentially enabling it to better compete for light. This supports observations that yield loss in corn caused by velvetleaf interference is primarily due to competition for light (Lind- quist and Mortensen 1999). Root:shoot ratio of corn in the 7.5 to $40.9 \mathrm{~g} \mathrm{plant}^{-1}$ size class (V6 to V13) was $45 \%$ greater in the no $\mathrm{N}$ compared to the high $\mathrm{N}$ treatment in 2001, whereas velvetleaf root:shoot ratio was $46 \%$ greater. In contrast, root:shoot ratio of corn in the two smallest size classes was 44 and 29\% greater in the no N compared to the high $\mathrm{N}$ treatment in 2002, while velvetleaf root:shoot ratio in the 1 to $24.9 \mathrm{~g}$ plant $^{-1}$ size class was $82 \%$ greater (Table 1 ). Differences in $\mathrm{N}$ treatment ( 3 compared to $6 \mathrm{~g} \mathrm{~N}$ per pot) might have contributed to the greater reduction in velvetleaf root:shoot ratio in response to $\mathrm{N}$ supply in 2002. Root: shoot ratio did not vary among $\mathrm{N}$ treatments when corn

TABLE 1. Mean (untransformed) corn and velvetleaf root:shoot ratio across nitrogen treatments in different size classes in 2001 and 2002. Within columns and years, means followed by different letters are different at $\mathrm{P}<0.05$ (unless otherwise specified).

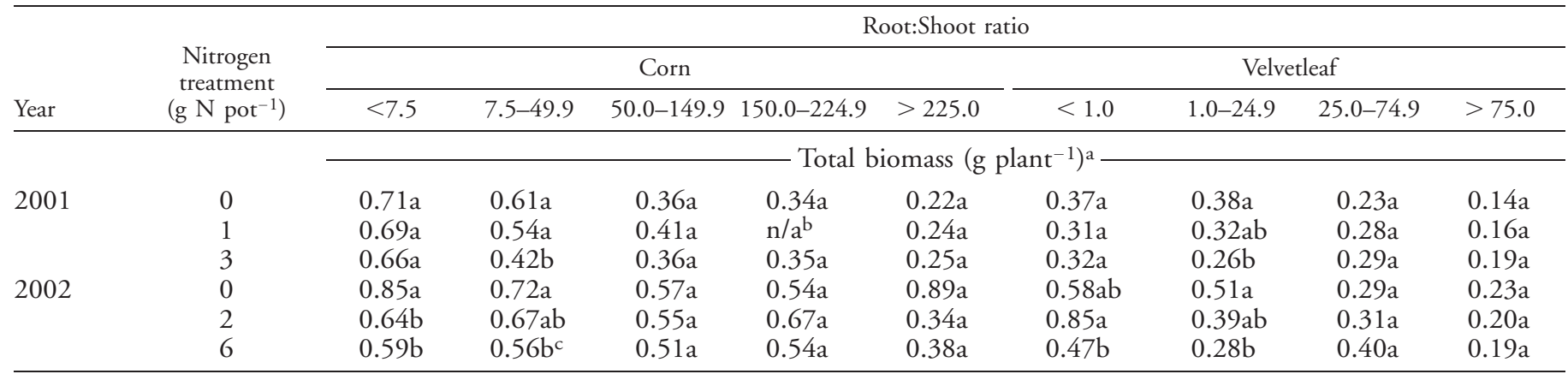

${ }^{a}$ Corn size classes corresponded approximately to growth stage as follows: $<7.5$ g plant $^{-1}=\mathrm{VE}$ to V6; $7.5-49.9 \mathrm{~g}$ plant ${ }^{-1}=\mathrm{V} 6$ to $^{\mathrm{V} 13}$; $50.0-149.9$ g plant ${ }^{-1}=\mathrm{V} 13$ to V16; $150.0 \mathrm{~g} \mathrm{plant}^{-1}$ and greater $=\mathrm{V} 16$ to $\mathrm{R} 2$.

$\mathrm{b} \mathrm{n} / \mathrm{a}$ indicates no plants occurred within this size class in this treatment.

${ }^{c}$ Means differ at $\mathrm{P}=0.06$. 


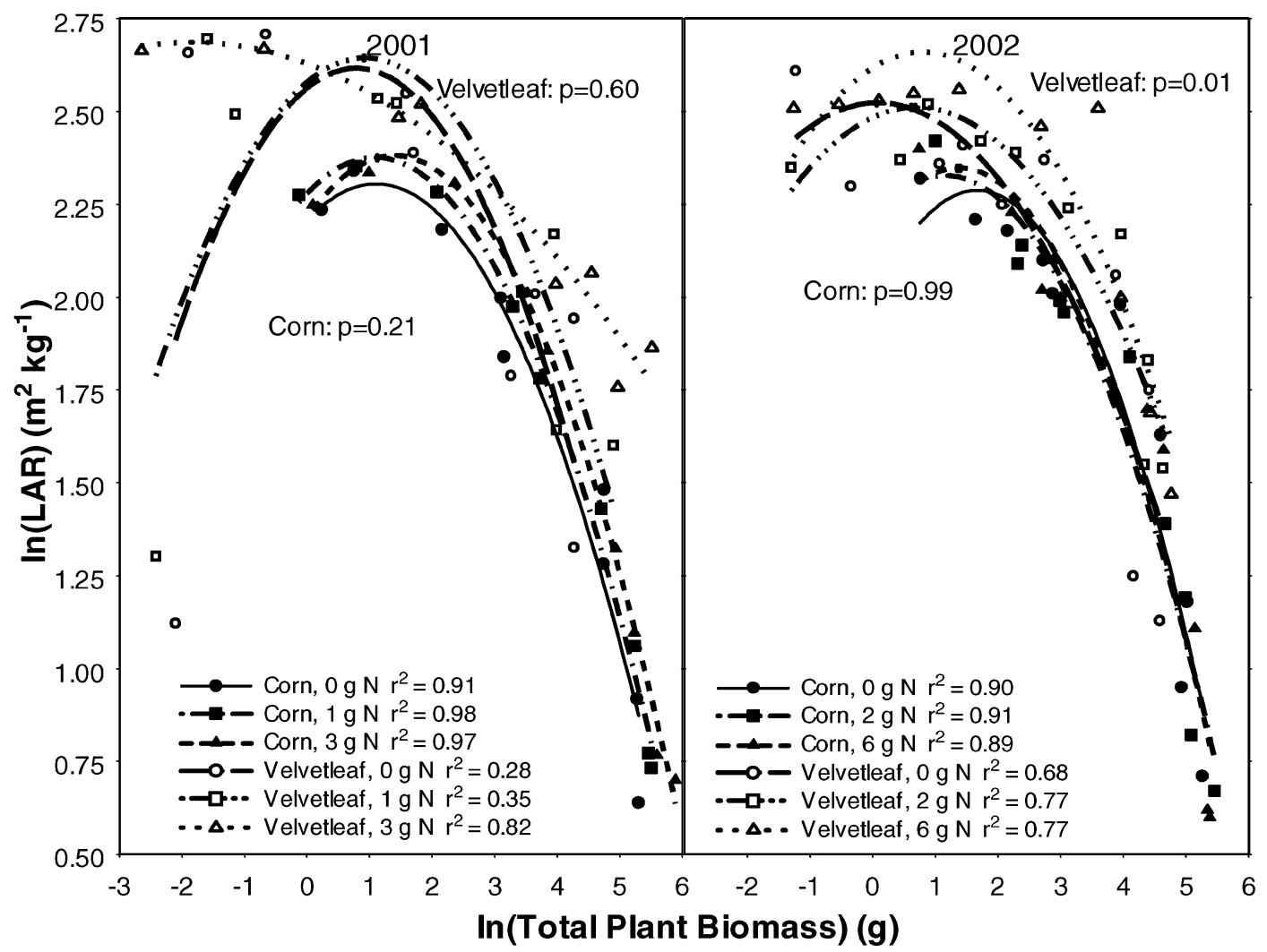

Figure 3. Natural log of leaf area ratio (LAR, $\mathrm{m}^{2}$ leaf $\mathrm{kg}^{-1}$ total plant biomass) plotted as a function of natural log of total plant biomass in 2001 and 2002. Curves represent best-fit second order polynomial regressions, and $r^{2}$ values indicate goodness of fit. Probability values for each species correspond to the test that leaf area ratio did not differ across nitrogen treatments.

was greater than $50 \mathrm{~g}$ plant $^{-1}(\mathrm{~V} 13+)$ and velvetleaf was greater than $25 \mathrm{~g}_{\text {plant }}{ }^{-1}$.

Corn LAR declined with increasing biomass, but did not vary with $\mathrm{N}$ supply in either year. Velvetleaf LAR declined with increasing biomass, but also increased with increasing nitrogen supply in 2002 (Figure 3). It is possible that the decline in velvetleaf root:shoot ratio with increasing $\mathrm{N}$ supply in 2001 was not sufficiently great to detect differences in LAR in that year, whereas the root:shoot response to $\mathrm{N}$ supply was much greater in 2002. McConnaughay and Coleman (1999) showed a decrease in velvetleaf LAR when N was limiting. Velvetleaf is forced to partition more biomass to its roots when $\mathrm{N}$ is limiting, and in accordance with optimal partitioning theory, this increase in root biomass comes at the expense of shoot biomass. The decrease in LAR observed in velvetleaf at low $\mathrm{N}$ in 2002 indicates that velvetleaf might not be able to compete as well for light when $\mathrm{N}$ is limiting.

Results of this study indicate that both corn and velvetleaf increase biomass partitioning to roots as $\mathrm{N}$ supply decreases. However, velvetleaf allocates a relatively greater percentage of its biomass to roots when $\mathrm{N}$ is limiting to maintain $\mathrm{N}$ uptake and photosynthesis. This means that when $\mathrm{N}$ becomes limiting, velvetleaf partitions more biomass to roots and less to shoots, inhibiting its ability to compete as well for light. When $\mathrm{N}$ is not in full supply, velvetleaf might not be as strong a competitor with corn. $\mathrm{N}$ supply plays an important role in the interaction between aboveground and belowground competition for resources, and the amount of $\mathrm{N}$ available to corn and velvetleaf will affect the outcome of competition between the two species.

\section{Sources of Materials}

${ }^{1}$ LI-3000, LiCor, 4308 Progressive Ave., Lincoln, NE 68504.

2 Optic StowAway, Onset Computer Corporation, 470 MacArthur Blvd., Bourne, MA 02532.

3 SAS Institute Inc., 100 SAS Campus Drive, Cary, NC 275132414.

\section{Acknowledgments}

A contribution of the University of Nebraska Agricultural Research Division, Lincoln, NE. Journal Series No. 14904. This research was supported in part by funds provided by the Hatch Act and by the State of Nebraska.

\section{Literature Cited}

Bazzaz, F. A., K. Garbutt, E. G. Reekie, and W. E. Williams. 1989. Using growth analysis to interpret competition between a $\mathrm{C}_{3}$ and $\mathrm{C}_{4}$ annual under ambient and elevated $\mathrm{CO}_{2}$. Oecologia 79:223-235.

Brown, R. H. 1978. A difference in $\mathrm{N}$ use efficiency in $\mathrm{C}_{3}$ and $\mathrm{C}_{4}$ plants and its implications in adaptation and evolution. Crop Sci. 18:93-98.

Brown, R. H. 1985. Growth of $\mathrm{C}_{3}$ and $\mathrm{C}_{4}$ grasses under low $\mathrm{N}$ levels. Crop Sci. 25:954-957.

Coleman, J. S., K.D.M. McConnaughay, and D. D. Ackerly. 1994. Interpreting phenotypic variation in plants. Trends Ecol. Evol. 9:187-191.

Evans, G. C. 1972. The Quantitative Analysis of Plant Growth. Berkeley, CA: University of California Press. 734 p.

Gedroc, J. J., K.D.M. McConnaughay, and J. S. Coleman. 1996. Plasticity in root/shoot partitioning: optimal, ontogenetic, or both? Funct. Ecol. $10: 44-50$

Harmens, H., J. F. Farrar, C. Marshall, and C. M. Stirling. 2000. Is partitioning of dry weight and leaf area within Dactylis glomerata affected by $\mathrm{N}$ and $\mathrm{CO}_{2}$ enrichment? Ann. Bot. 86:833-839.

Hilbert, D. W. 1990. Optimization of plant root:shoot ratios and internal nitrogen concentration. Ann. Bot. 66:91-99. 
Liebman, M., C. L. Mohler, and C. P. Staver. 2001. Ecological management of agricultural weeds. Cambridge, Great Britain: Cambridge University Press. 532 p.

Lindquist, J. L. and D. A. Mortensen. 1999. Ecophysiological characteristics of four corn hybrids and Abutilon theophrasti. Weed Res. 39:271285.

Lindquist, J. L., D. A. Mortensen, A. Clay, R. Schmenk, J. J. Kells, K. Howatt, and P. Westra. 1996. Stability of corn (Zea mays)-velvetleaf (Abutilon theophrasti) interference relationships. Weed Sci. 44:309313.

Littell, R. C., G. A. Milliken, W. W. Stroup, and R. D. Wolfinger. 1996. SAS ${ }^{\circledR}$ System for mixed models. Cary, NC: SAS Institute.

McConnaughay, K.D.M. and J. S. Coleman. 1999. Biomass allocation in plants: ontogeny or optimality? A test along three resource gradients. Ecology 80:2581-2593.

Mooney, H. A., A. J. Bloom, and F. S. Chapin, III. 1985. Resource limitation in plants-an economic analogy. Ann. Rev. Ecol. Syst. 16:36392.
Murphy, C. and J. L. Lindquist. 2002. Growth response of velvetleaf to three post emergence herbicides. Weed Sci. 50:364-369.

Reynolds, H. L. and C. D'Antonio. 1996. The ecological significance of plasticity in root weight ratio in response to nitrogen: opinion. Plant Soil. 185:75-97.

Robinson, D. 1986. Compensatory changes in the partitioning of dry matter in relation to nitrogen uptake and optimal variations of growth. Ann. Bot. 58:841-848.

Roeth, F. W. 1987. Velvetleaf-coming on strong. Crops Soil Mag. 39:1011.

Sage, R. F. and R. W. Pearcy. 1987. The nitrogen use efficiency of $C_{3}$ and $\mathrm{C}_{4}$ plants. Plant Physiol. 84:954-958.

Spencer, N. R. 1984. Velvetleaf, Abutilon theophrasti, history and economic impact in the United States. Econ. Bot. 38(4):407-416.

USDA. 2005. National Agricultural Statistics Service. (NASS) Agricultural Statistics 2005. http://www.usda.gov/nass/pubs/agr05/acro05.htm.

Received January 13, 2005, and approved May 26, 2005. 